\title{
Comparative study of in vitro effects of different nanoparticles at non-cytotoxic concentration on the adherens junction of human vascular endothelial cells
}

This article was published in the following Dove Press journal:

International Journal of Nanomedicine

\author{
Tao Wen ${ }^{1} *$ \\ Aiyun Yang ${ }^{1, *}$ \\ Lingyu Piao ${ }^{2}$ \\ Suisui Hao' \\ Lifan Du' \\ Jie Meng' \\ Jian Liu' \\ Haiyan Xu' \\ 'Institute of Basic Medical Sciences, \\ Chinese Academy of Medical Sciences \& \\ Peking Union Medical College, Beijing \\ 100005, People's Republic of China; ${ }^{2}$ CAS \\ Center for Excellence in Nanoscience, \\ CAS Key Laboratory of Standardization \\ and Measurement for Nanotechnology, \\ National Center for Nanoscience and \\ Technology, Beijing, 100190, People's \\ Republic of China
}

*These authors contributed equally to this work
Correspondence: Haiyan Xu Institute of Basic Medical Sciences, Chinese Academy of Medical Sciences \& Peking Union Medical College, 5 Dong Dan San Tiao, Dongcheng District, Beijing 100005, People's Republic of China

Email xuhy@pumc.edu.cn
Background: Effects of different nanoparticles (NPs) exposure at acutely non-cytotoxic concentrations are particularly worthy to figure out, compare, and elucidate.

Objective: To investigate and compare the effect of a small library of NPs at non-cytotoxic concentration on the adherens junction of human umbilical vein endothelial cells (HUVECs), obtaining new insights of NPs safety evaluation.

Materials and methods: The HUVECs layer was exposed to NPs including gold (Au), platinum $(\mathrm{Pt})$, silica $\left(\mathrm{SiO}_{2}\right)$, titanium dioxide $\left(\mathrm{TiO}_{2}\right)$, ferric oxide $\left(\mathrm{Fe}_{2} \mathrm{O}_{3}\right)$, oxidized multi-walled carbon nanotubes, with different surface chemistry and size distribution. Cellular uptake of NPs was observed by transmission electron microscopy. and the cytotoxicity was determined by Cell Counting Kit-8 assay. The NP-induced variation of intracellular reactive oxygen species (ROS) and catalase (CAT) activity was measured using the probe of 2'7'-dichlorodihydr fluorescein diacetate and a CAT analysis kit, respectively. The level of VE-cadherin of HUVECs was analyzed by Western blot, and the loss of adherens junction was observed with laser confocal microscopy.

Results: The acutely non-cytotoxic concentrations of different NPs were determined and applied to HUVECs. The NPs increased the level of intracellular ROS and the activity of CAT to different degrees, depending on the characteristics. At the same time, the HUVECs lost their adherens junction protein VE-cadherin and gaps were formed between the cells. The NP-induced oxidative stress and gap formation could be rescued by the supplementary $\mathrm{N}$-acetylcysteine in the incubation.

Conclusion: The increase of intracellular ROS and CAT activity was one common effect of NPs, even at the non-cytotoxic concentration, and the degree was dependent on the composition, surface chemistry, and size distribution of the NP. The effect led to the gap formation between the cells, while could be rescued by the antioxidant. Therefore, the variation of adherens junction between endothelial cells was suggested to evaluate for NPs when used as therapeutics and diagnostics.

Keywords: reactive oxygen species (ROS), catalase, HUVEC, VE-cadherin

\section{Introduction}

Engineered nanoparticles (NPs) have been attracting growing research and development interests as well as serious concerns for how to find out and properly evaluate their impacts on the biological system due to their unique physicochemical characteristics and uncertainty of biological effects. ${ }^{1}$ In particular, NPs that are 
intended for uses in therapy and diagnosis are likely to enter into the blood circulating system by various exposure ways. On the wall of blood vessels, there is an endothelial layer composed of endothelial cells connecting each other, which is the most important biological barrier between blood and tissues to maintain the vascular function and of homeostasis. $^{2-4}$ The injury of the endothelial layer may result in acute inflammation, ${ }^{5,6}$ leading to various pathophysiological conditions, such as atherosclerosis, thrombosis, and myocardial infarction. ${ }^{7,8}$

Interactions between NPs and endothelial cells have been investigated in previous reports. The multiplicity of NPs includes gold $(\mathrm{Au})$, platinum $(\mathrm{Pt})$, silica $\left(\mathrm{SiO}_{2}\right)$, titanium dioxide $\left(\mathrm{TiO}_{2}\right)$, iron(III) oxide $\left(\mathrm{Fe}_{2} \mathrm{O}_{3}\right)$, iron(II,III) oxide $\left(\mathrm{Fe}_{3} \mathrm{O}_{4}\right)$, Zinc oxide $(\mathrm{ZnO})$, copper (II) oxide $(\mathrm{CuO})$, magnesium oxide $(\mathrm{MgO})$, aluminum oxide $\left(\mathrm{Al}_{2} \mathrm{O}_{3}\right)$, and multi-walled carbon nanotubes (MWCNTs). ${ }^{9-19}$ The exposure dosage, size distribution, and surface modification of NPs employed in the previous literatures were largely various, even for the same kind of NPs, which lead to hard comparisons among their biological effects. Take Au NPs as an example, the size range is from 10 to $50 \mathrm{~nm}$, and the concentration range employed with vascular endothelial cells was from $100 \mathrm{nM}$ to $100 \mu \mathrm{M}$ in different labs. ${ }^{9,20}$ It has been recognized that in addition to inducing cells death, NPs are able to affect the integrity of vascular endothelial layer, for examples, titanium dioxide $(23.5 \mathrm{~nm}$, at $10 \mu \mathrm{M}$ ) was demonstrated to cause endothelial cell leakiness through physical interactions. ${ }^{14}$ Similarly, effects of six kinds of metal oxide NPs on human cardiac microvascular endothelial cells are reported, the exposed concentration of the NPs ranges from 0.001 to $100 \mu \mathrm{g} / \mathrm{mL}$, and average diameter is about $40 \mathrm{~nm}$. Among them, NPs of $\mathrm{ZnO}, \mathrm{CuO}$, and $\mathrm{MgO}$ increase lactate dehydrogenase of vascular endothelial cells, while NPs of $\mathrm{Fe}_{2} \mathrm{O}_{3}, \mathrm{Fe}_{3} \mathrm{O}_{4}$. and $\mathrm{Al}_{2} \mathrm{O}_{3}$ have no significant effects on the permeability. ${ }^{18}$ In addition, NPs of $\mathrm{Fe}_{2} \mathrm{O}_{3}(50 \mu \mathrm{g} / \mathrm{mL}$, with a mean diameter of $298 \mathrm{~nm}),{ }^{17}$ MWCNTs $(3.86 \mu \mathrm{m}$ long, $2.5 \mu \mathrm{g} / \mathrm{mL}),{ }^{11}$ and silver NPs $(110 \mathrm{~nm}, 1 \mu \mathrm{g} / \mathrm{mL})^{21}$ affect VE-cadherin expression by increasing intracellular reactive oxygen species (ROS). However, at acutely non-cytotoxic concentration, effects of NPs on endothelial cells have little touched yet, which are particularly worthy to note, because there may be some unseen biological effects.

In this study, we selected six kinds of NPs, including $\mathrm{Au}, \mathrm{Pt}, \mathrm{SiO}_{2}, \mathrm{TiO}_{2}, \mathrm{Fe}_{2} \mathrm{O}_{3}$, and MWCNTs, with different size, surface chemistry, and composition to set up a small library. By screening the cytotoxicity of each kind of the
NPs, we had endothelial cells exposed to the different NPs at acutely non-cytotoxic concentrations, investigating the effects of the NPs on the adherent conjunction of vascular endothelial cells and underlying reasons.

\section{Materials and methods Materials}

Dextran- $\mathrm{Fe}_{2} \mathrm{O}_{3}$, DMSA- $\mathrm{Fe}_{2} \mathrm{O}_{3}$ NPs were provided by the Nanjing Nanoeast Biotech Co., Ltd. TiO 2 NPs (25, 30, 80, $100 \mathrm{~nm}$ ) were provided by Prof. Lingyu Piao, National Center for Nanoscience and Technology, China. $\mathrm{SiO}_{2}(20$, $50,100 \mathrm{~nm})$ and platinum NPs $(5,30,70 \mathrm{~nm})$ were purchased from the nanocomposix company. The product of original multi-walled carbon nanotube $(50 \mu \mathrm{m})$ was purchased from Chengdu Organic Chemicals Co., Ltd., Chinese Academy of Sciences. Oxidized multi-walled carbon nanotubes and gold NPs $(10,30,50 \mathrm{~nm})$ were synthesized according to protocols of references. ${ }^{22-24}$ Milli-Q water $(18 \mathrm{M} \Omega \mathrm{cm})$ was used for the preparation of all solutions.

\section{Size and charge}

Dynamic light scattering analysis (Nano ZS90, Malvern Instruments Ltd, UK) was used to measure the hydrodynamic diameter and Zeta potential of particles. In short, the solutions of NPs were dispersed in $1 \mathrm{~mL}$ Milli-Q water or serum containing medium. Each measurement was repeated three times.

\section{Cell culture}

Primary human umbilical vein endothelial cells (HUVECs), endothelial cell medium, endothelial cell growth supplements, and Poly-L-Lysine were all purchased from ScienCell Research Laboratories (San Diego, CA). Cells were grown on a cell culture plates coated with $1 \mu \mathrm{g} \mathrm{cm}^{-2}$ poly-L-lysine, and cultured at $37^{\circ} \mathrm{C}$ in a wet incubator with $5 \% \mathrm{CO}_{2}$.

\section{Cell viability assay}

HUVECs were seeded into 96-well cell culture plates at a density of $1.5 \times 10^{4}$ cells/well and cultured $24 \mathrm{hrs}$ for adherence. The cells were incubated with $100 \mu \mathrm{L}$ NPs at $37^{\circ} \mathrm{C}$ for $24 \mathrm{hrs}$, followed by washing with PBS and incubated with fresh medium containing $10 \mu \mathrm{L}$ Cell Counting Kit-8 (CCK-8, Dojindo Molecular Technologies, Inc) for $2 \mathrm{hrs}$. The absorbance of the medium was measured at $450 \mathrm{~nm}$ using the Synergy H1 hybrid 
multifunction microplate reader (BioTek Instruments, Winooski, VT, USA). The measurements were carried out in three parallel lines, and the relative cell viability was expressed as a percentage of the control.

\section{Cell uptake assay through transmission electron microscopy (TEM)}

HUVECs were seeded at a density of $1.5 \times 10^{6}$ cells/dish in a $100 \mathrm{~mm}$ dish and incubated overnight for cell attachment. The cells were treated with NPs for $24 \mathrm{hrs}$. Then, cells were washed twice with PBS, scraped gently from the dishes and centrifuged, then fixed with $2.5 \%$ glutaraldehyde (Fluka) and dehydrated gradually by alcohol and embedded in epon. Sections were then cut and placed on copper grids for observation (TEM-1400 plus, JEOL Ltd., Tokyo, Japan). In the process, NPs were dyed with Uranium acetate and lead citrate dyeing except Dex- $\mathrm{Fe}_{2} \mathrm{O}_{3}$.

\section{Intracellular ROS measurement}

HUVECs were seeded at a density of $1 \times 10^{5}$ cells/well in the 24-well cell culture plate and kept overnight to adhere. For the rescue experiment, the cells were treated with $3 \mathrm{mM}$ $\mathrm{N}$-acetylcysteine (NAC; Sigma-Aldrich, USA) for $1 \mathrm{hr}$ before exposure to NPs. The cells were treated with NPs for $1 \mathrm{hr}$ at $37^{\circ} \mathrm{C}$ and then washed with PBS. After that, PBS containing 10 $\mu \mathrm{M}$ DCFH-DA (Sigma-Aldrich, USA) was added at $37^{\circ} \mathrm{C}$ for 30 mins and then washed with PBS twice. Finally, the cells were detached from the plates with $100 \mu \mathrm{L}_{\text {well }}{ }^{-1}$ trypsin, and collected by centrifugation. Flow cytometric analysis was conducted on the various cell treatment groups, using an excitation wavelength of $488 \mathrm{~nm}$ and emission wavelength of $525 \mathrm{~nm}$ (AccuriTM C6 flow cytometer, BD Biosciences, San Jose, CA). All groups had three replicate wells.

\section{Catalase (CAT) activity}

HUVECs were grown at a density of $7 \times 10^{5}$ cells well $^{-1}$ on six well plates overnight and exposed to NPs for $1 \mathrm{hr}$ at $37^{\circ} \mathrm{C}$. Subsequently, cells were washed twice with PBS and scraped using $100 \mu \mathrm{L}$ of RIPA buffer (PMSF: RIPA=1:100). The samples were centrifuged at 2,500 rpm for 10 mins at $4^{\circ} \mathrm{C}$. Then, cell extracts were collected for measurement of CAT activity using a CAT analysis kit (Nanjing Jiancheng Biology Engineering Institute, China). Then, the absorbance of the medium was measured at $405 \mathrm{~nm}$ using the Synergy H1 hybrid multifunction microplate reader. All groups had three replicate wells.

\section{Immunostaining and laser confocal microscopy assay}

HUVECs were seeded at a density of $1 \times 10^{5}$ cells/well in 24-well cell culture plates (pre-loaded with cell climbing glass slices) and incubated overnight for adhesion. To carry out the rescue experiment, the cells were treated with $3 \mathrm{mM}$ NAC for $1 \mathrm{hr}$ before exposure to the NPs. The cells were treated with medium containing NPs for $1 \mathrm{hr}$ and fixed with $4 \%$ polyformaldehyde at $37^{\circ} \mathrm{C}$ for 30 mins, permeabilized using $0.3 \%$ TritonX-100 for 15 mins. After rinsing with PBS and incubated with 2\% BSA for $1 \mathrm{hr}$, the cells were labeled with VE-cadherin XPTM Rabbit antibody (1:200 dilution, Cell Signaling Technology, USA) in 2\% BSA/PBS overnight at $4{ }^{\circ} \mathrm{C}$ followed by washed with PBS and incubated with Goat anti-rabbit antibody labeled with Alexa Fluor488 (1:400 dilution, Cell Signaling Technology) and mounted with an aqueous mounting medium containing DAPI (Zhongshan Goldenbridge biotechnology Co., China). The microphotographs were taken by using the FluoView FV1000 confocal microscope (Olympus). Each group was repeated three times.

\section{Western blot}

HUVECs were seeded at a density of $6 \times 10^{5}$ cells/well in six-well cell culture plates and incubated overnight and then incubated with the medium containing NPs for $1 \mathrm{hr}$. After washed with PBS and scraped using RIPA buffer (PMSF: RIPA=1:100), the cells were centrifuged at $12,000 \mathrm{rpm}$ for $15 \mathrm{mins}$ at $4^{\circ} \mathrm{C}$, and the supernatants were collected. Protein concentrations were determined using PierceTM BCA Protein Assay Kit (Thermo Fisher Scientific, USA). Proteins (30 $\left.\mu \mathrm{g}_{\text {lane }}{ }^{-1}\right)$ were resolved by means of SDS-PAGE and electrotransferred onto PVDF membranes (Millipore, Bedford, Massachusetts). The membranes were blocked using TBST containing 5\% skim milk, and then incubated overnight at $4{ }^{\circ} \mathrm{C}$ with primary antibodies (VE-cadherin XPTM Rabbit antibody, Cell Signaling Technology). The membranes were next incubated for $2 \mathrm{hrs}$ at room temperature with horseradish peroxidase conjugated secondary IgGs (1:10,000). Finally, the immunoreactive bands were visualized with the Immobilon $^{\circledR}$ Western HRP Substrate luminal reagent and peroxide solution (Millipore Corporation, Billerica).

\section{Measurement of endothelial permeability}

HUVECs were seeded in 24-well cell culture plates containing cell climbing glass slices that had been pre-loaded 
with collagen and incubated for two days. The cells were treated with NPs for $1 \mathrm{hr}$ at $37^{\circ} \mathrm{C}$, which was then washed before being immersed in $18 \mu \mathrm{M} 40 \mathrm{kDa}$ FITC-dextran (Sigma-Aldrich) for 5 mins. Thereafter, follow the procedure in laser confocal microscopy assay. Confocal $\mathrm{Y}$ and Z-slice images were taken by a confocal microscope. For data analysis, a rectangle box of about $510 \times 70$ pixels in each cell layer was calculated as the boundary with ImageJ. The upper rectangle frame represented the average pixel intensity of $18 \mu \mathrm{M}$ FITC-dextran strength. A second box of width 510 pixels was drawn below the cell layer, containing the whole height of collagen, which represents the average pixel intensity of FITC-dextran that has entered the collagen. The accumulation of dextran was calculated by dividing the average pixel intensity within the collagen by that above the collagen.

\section{Statistical analysis}

Statistical significance was ascertained through Student's two-tailed $t$-test with SPSS software (SPPS17.0). ${ }^{*} P<0.05$, $* * P<0.01$, respectively.

\section{Results}

\section{Characterization of NPs}

The characteristics of employed NPs, including composition, particle size, and coating are summarized in Table 1. Images from the transmission electron microscope (TEM) showed morphologies of the NPs dispersed in aqueous solution (Figure 1). Most of the selected particles are spherical except for MWCNTs having a tubular structure. For the particles with the same composition, the smaller one is likely to aggregate in aqueous solution. From the TEM images of HUVECs incubated with NPs for 24 hrs, most of the NPs were included in the vesicles and especially in the lysosomes structures. While, Dex- $\mathrm{Fe}_{2} \mathrm{O}_{3}$ NPs were more located in the junction area of the cells (Figure 2).

\section{Cytotoxicity of NPs on HUVECs}

In order to determine the acutely non-cytotoxic concentration for each kind of the NPs, the viability of HUVECs incubated with the NPs for 24 hrs was measured (Figure 3). Different concentration ranges of NPs were employed firstly to obtain the acutely non-cytotoxic concentration for each NP. The cell viability of control group was set as a $100 \%$. In general, the effect of NPs on the cell viability was closely associated with the NPs composition (Au, Pt, MWCNT), coating (Dex-/ DMSA-Fe $\left.\mathrm{O}_{3}\right)$, and size $\left(\mathrm{TiO}_{2}, \mathrm{SiO}_{2}\right)$. Au NPs did not affect the viability of HUVEC in the range of testing concentration, possibly due to the sodium citrate on the surface, ${ }^{25,26}$ while $\mathrm{Pt}$ NPs modified with the same sodium citrate reduced the viability of HUVECs in a concentration-dependent manner, which was attributed to the chemical property of Pt. Pt-5 showed greater cytotoxicity than Pt-30 and Pt-70 due to the larger specific surface area of the smaller particles. Similar to Pt NPs, $\mathrm{TiO}_{2}$ NPs affected the viability of HUVEC. Among the four $\mathrm{TiO}_{2} \mathrm{NPs}_{\mathrm{S}} \mathrm{TiO}_{2}-25$ was more cytotoxic than the pure anatase type in a dose-dependent manner. The cytotoxicity of $\mathrm{SiO}_{2}-100$ was weaker than that of $\mathrm{SiO}_{2}-20$ and $\mathrm{SiO}_{2}-50$, while $\mathrm{SiO}_{2}-50$ was more toxic than $\mathrm{SiO}_{2}-20$, this is possibly due to the aggregation of $\mathrm{SiO}_{2}-20$, evidenced by that the average dynamic diameter of $\mathrm{SiO}_{2}-20$ in the culture medium was $202.37 \pm 0.25 \mathrm{~nm}$, which led to the decrease of specific surface area to a certain degree and lower cytotoxicity. It was also observed the cytotoxic effect of $\mathrm{SiO}_{2}-20$ and $\mathrm{SiO}_{2}-50$ was associated with the exposure concentration. The two types of magnetic iron oxide particles displayed different cytotoxicity. The Dex- $-\mathrm{Fe}_{2} \mathrm{O}_{3}$ NPs did not affect the cell viability until the content of $\mathrm{Fe}$ was higher than $240 \mu \mathrm{g} \mathrm{mL}^{-1}$, however, the DMSA-Fe $\mathrm{O}_{3}$ NPs showed significant cytotoxic and statistical

Table I The small library of NPs used in this work

\begin{tabular}{|l|l|l|l|l|}
\hline Category & Composition & Coating & Size (nm) & Abbreviation \\
\hline Metal & $\mathrm{Au}$ & $\begin{array}{l}\text { Sodium citrate } \\
\text { Sodium citrate }\end{array}$ & $\begin{array}{l}10 / 30 / 50^{\mathrm{a}} \\
5 / 30 / 70^{\mathrm{b}}\end{array}$ & $\begin{array}{l}\mathrm{Au}-10 / 30 / 50 \\
\mathrm{Pt}-5 / 30 / 70\end{array}$ \\
\hline & $\mathrm{Pt}$ & None & $20 / 50 / 100^{\mathrm{b}}$ & $\mathrm{SiO}-20 / 50 / 100$ \\
& $\mathrm{SiO}_{2}$ & None & $25 / 30 / 80 / 100^{\mathrm{c}}$ & $\mathrm{TiO}_{2}-25 / 30 / 80 / 100$ \\
& $\mathrm{TiO}_{2}$ & Dex & $30.15^{\mathrm{d}}$ & $\mathrm{Dex}^{\mathrm{Fe}} \mathrm{O}_{3}$ \\
& $\mathrm{Fe}_{2} \mathrm{O}_{3}$ & DMSA & $15.3 \pm 11.2^{\mathrm{d}}$ & $\mathrm{DMSA}^{\mathrm{Fe}} \mathrm{O}_{3}$ \\
\hline Carbonaceous & & None & $128.5 \pm 1.3^{\mathrm{a}}$ & $\mathrm{MWCNTs}$ \\
\hline
\end{tabular}

Note: ${ }^{a}$ Measured from DLS measurement, ${ }^{b}$ indicated on the label of products, ${ }^{c}$ measured from TEM images, ${ }^{\mathrm{d}}$ came from the reference.

Abbreviations: Dex, polydextrose sorbitol carboxymethyl ether; DMSA, 2, 3-dimercaptosuccinic acid; DLS, Dynamic light scattering. 


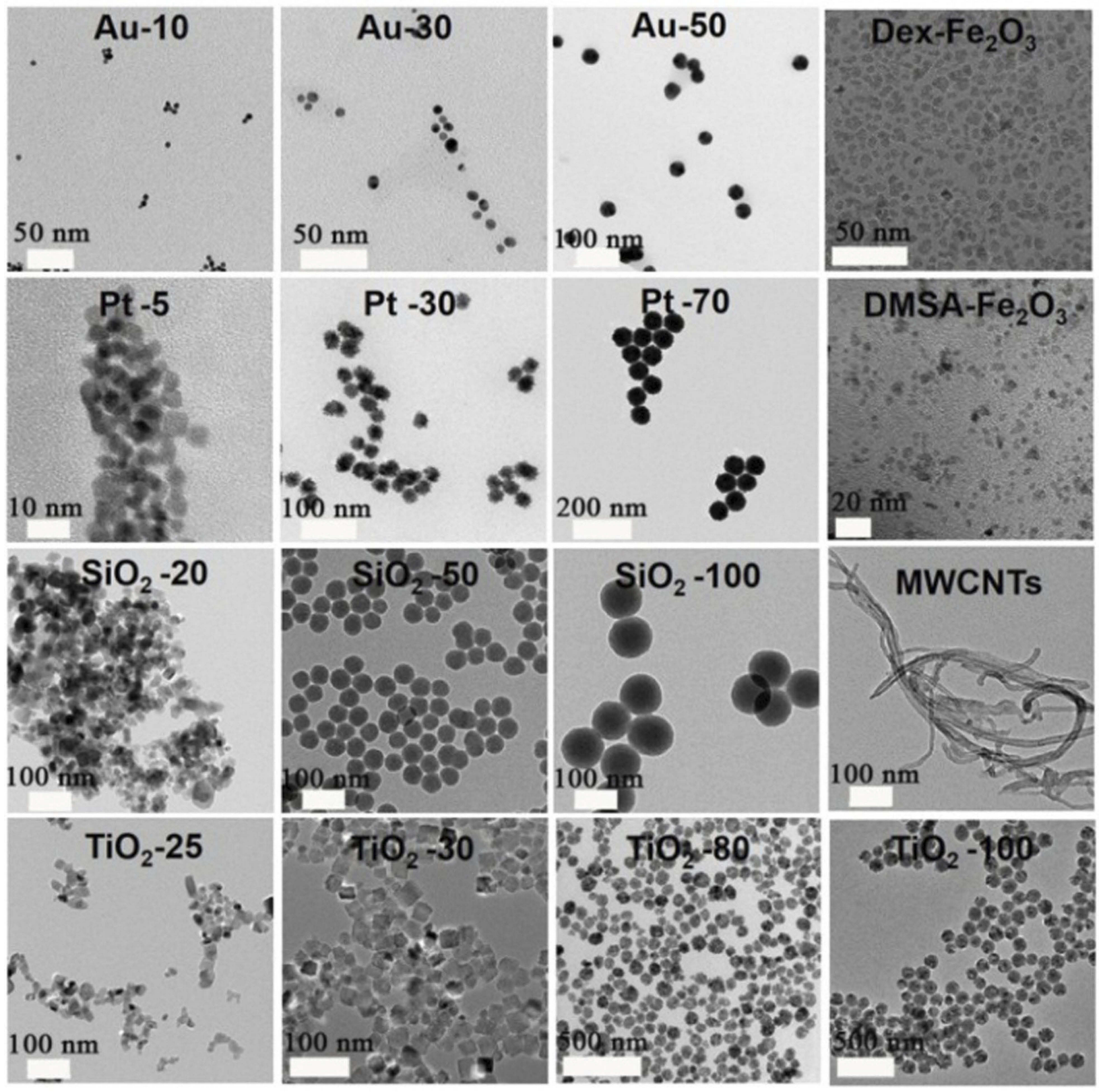

Figure I TEM images of various NPs employed in this work.

Abbreviations: Au, gold; Pt, platinum; SiO2, silica; TiO2, titanium dioxide; Fe2O3, iron(III) oxide; MWCNTs, multi-walled carbon nanotubes; Dex, polydextrose sorbitol carboxymethyl ether; DMSA, 2, 3-dimercaptosuccinic acid.

difference among the different concentrations when the content of Fe was higher than $30 \mu \mathrm{g} \mathrm{mL}^{-1}$. As for the MWCNTs, the cell viability was less affected when the concentration was not higher than $120 \mu \mathrm{g} \mathrm{mL}^{-1}$. Hence, we selected an acutely noncytotoxic concentration for each kind of the NPs, under which the cell viability was no less than $80 \%$ (rectangle in Figure 3).

\section{Oxidative stress induced by NPs}

As shown in Figure 4A, comparing with the untreated group, 1 $\mathrm{hr}$ of NPs exposure increased the intracellular ROS level, including Pt NPs, $\mathrm{SiO}_{2} \mathrm{NPs}, \mathrm{Fe}_{2} \mathrm{O}_{3} \mathrm{NPs}$, and MWCNTs. However, it was not detectable ROS variation for cells incubated with $\mathrm{TiO}_{2}$ NPs or Au NPs. It is well documented that when the extra ROS was produced, antioxidants in the cells would be increased to maintain the redox balance. ${ }^{27}$ To provide a side evidence of the other NPs increasing intracellular ROS, we examined the intracellular level of CAT because the increase of CAT is recognized as one crucial marker of ROS upregulation. ${ }^{28-30}$ Here, we examined the CAT variation in the cells incubated with the largest size of $\mathrm{Au} \mathrm{NPs}$ and $\mathrm{TiO}_{2} \mathrm{NPs}$ at the non-cytotoxic concentration reference to the untreated 

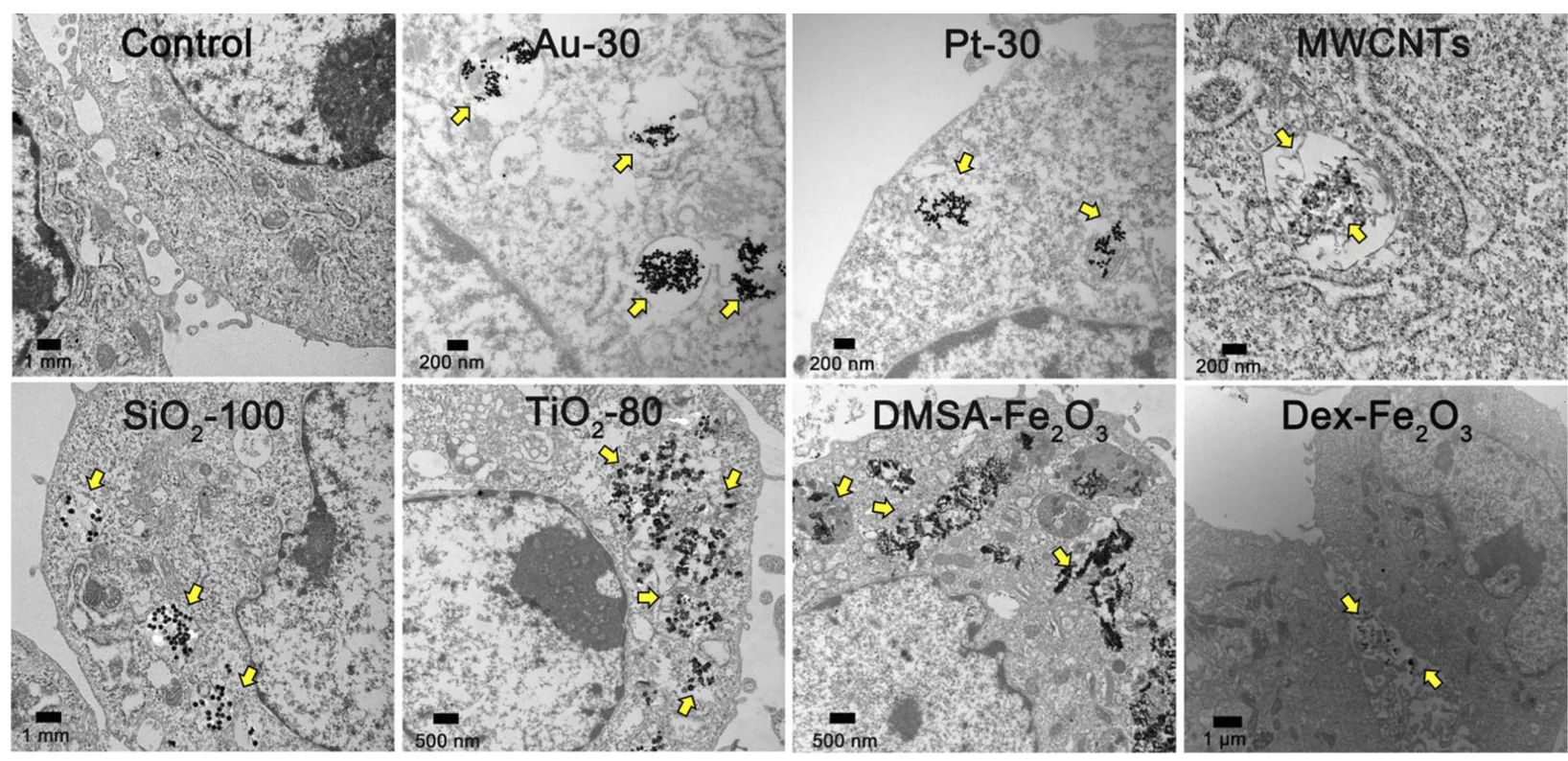

Figure 2 TEM images of cell uptake of various NPs. The NPs were distributed in/beside the cells as the arrow indicated.
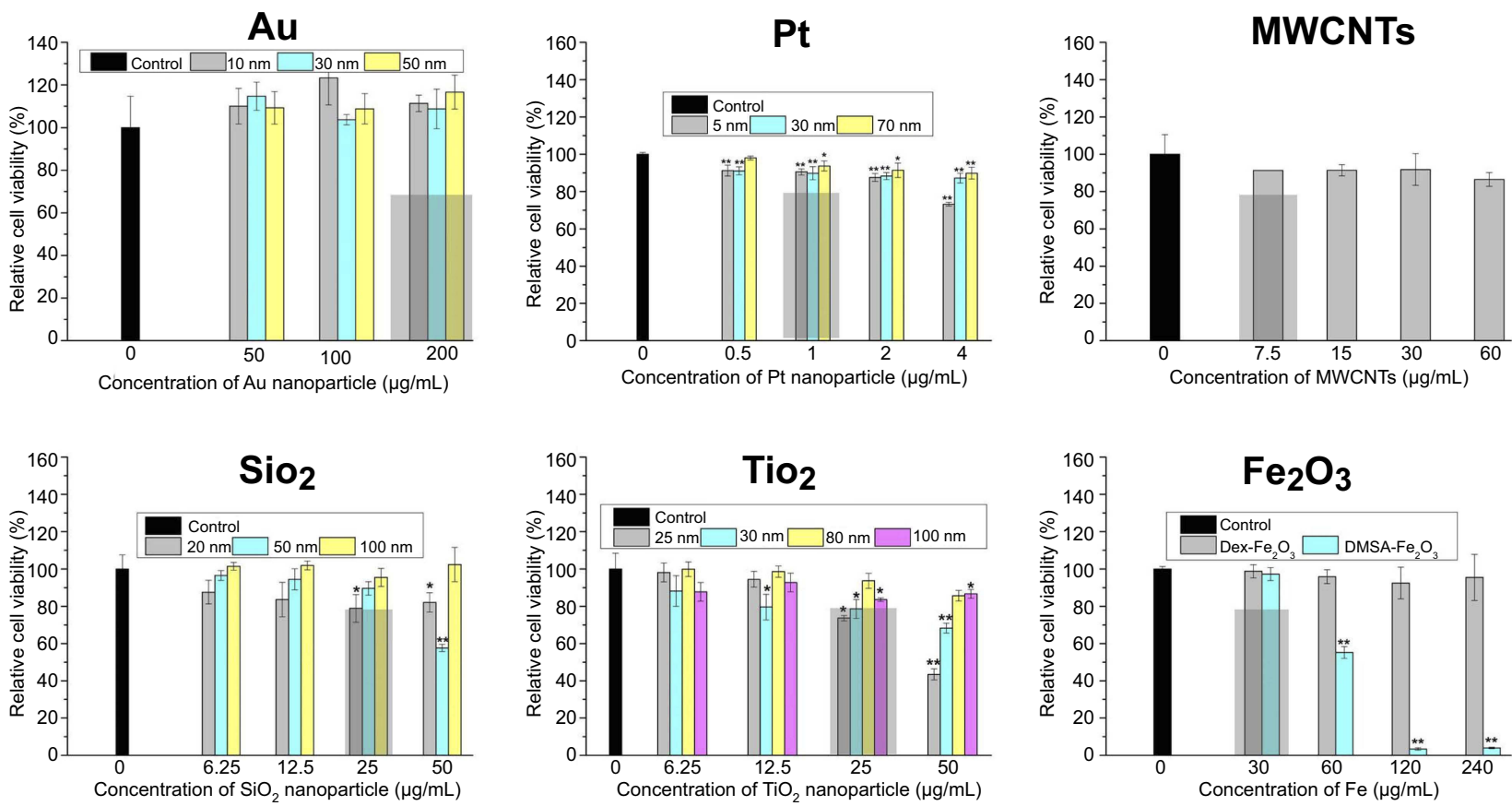

Figure 3 Viability of HUVECs exposed with NPs from CCK-8 assay. The * indicates significant differences between the control group and the nanoparticles treatment group (*: $P<0.05$, **: $P<0.01$ ).

group, at the same time, the effect of the largest size of Pt NPs and $\mathrm{SiO}_{2} \mathrm{NPs}$, and the other NPs on the CAT variation were examined as well. Results showed that each kind of NPs induced upregulation of CAT, the variation degree was associated with the chemistry of the NPs (Figure 4B). Taken above together, all the NPs were capable of inducing oxidative stress in the HUVECs to different degrees, and the Au NPs induced the weakest oxidative stress.

\section{Effects of NPs on adherens junction of HUVECs}

The upregulation of intracellular ROS level implied possible changes in endothelial cells functions. ${ }^{4}$ One of the most important proteins for vascular endothelial cells is VEcadherin that is essential for the adhesion junction between HUVECs, reflecting the integrity of vascular endothelial 

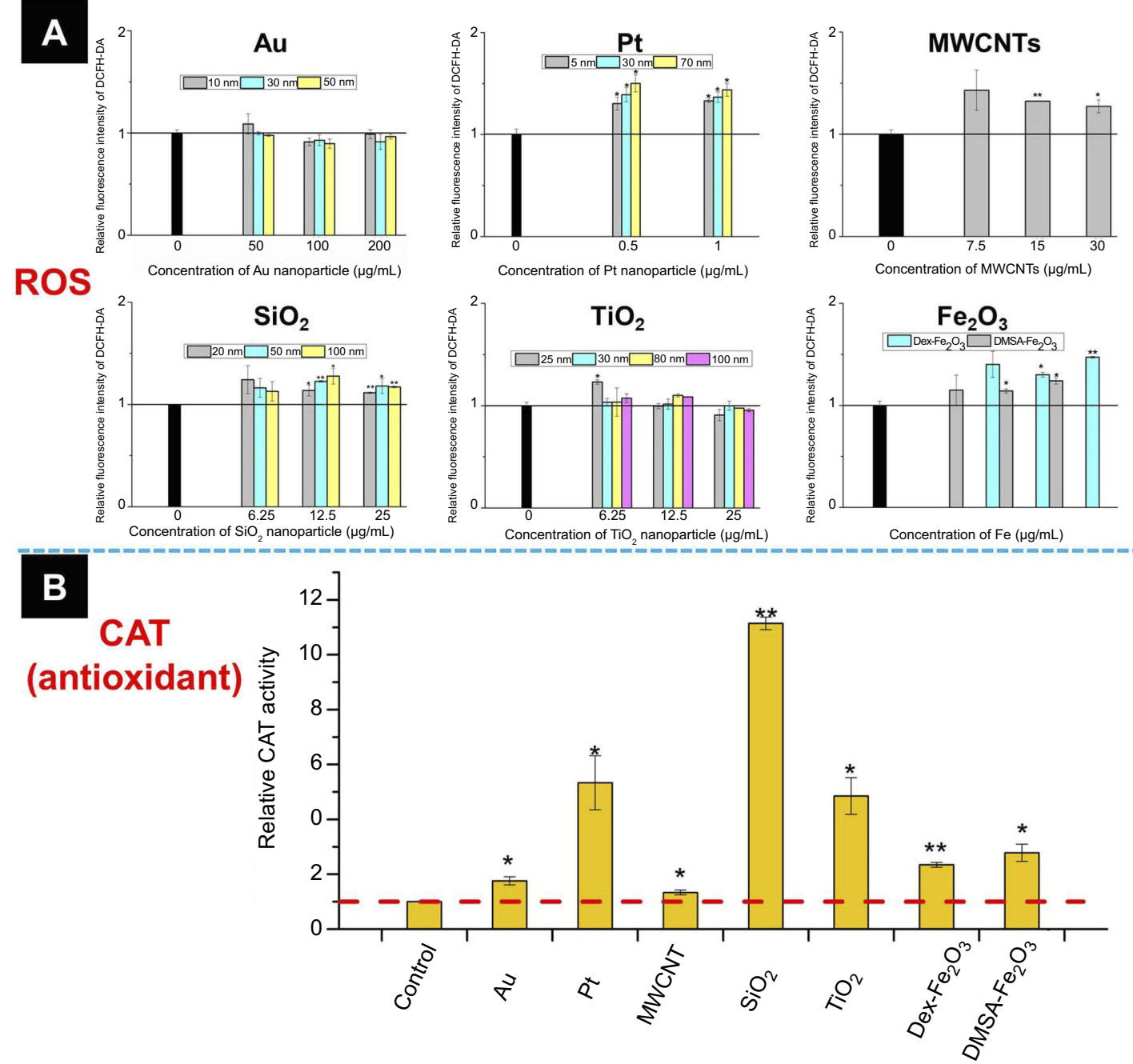

Figure 4 (A) The intracellular ROS level and (B) catalase activity of HUVECs incubated with various NPs. The concentration of NPs in (B) was listed below: Au (50 nm): $200 \mu \mathrm{g} \mathrm{mL}{ }^{-1}$, Pt $(70 \mathrm{~nm}):$ I $\mu \mathrm{g} \mathrm{mL}^{-1}$, MWCNTs: $7.5 \mu \mathrm{g} \mathrm{mL}{ }^{-1}, \mathrm{SiO}_{2}(100 \mathrm{~nm}): 25 \mu \mathrm{g} \mathrm{mL}{ }^{-1}, \mathrm{TiO}_{2}(100 \mathrm{~nm}): 25 \mu \mathrm{g} \mathrm{m}{ }^{-1}$, Dex-Fe $\mathrm{O}_{3}: 30 \mu \mathrm{g} \mathrm{Fe} \mathrm{mL}{ }^{-1}$, and DMSA-Fe $\mathrm{O}_{3}: 30 \mu \mathrm{g}$ Fe $\mathrm{mL}^{-1}$. *: $P<0.05$, **: $P<0.01$ compared with the control group.

Abbreviation: ROS, reactive oxygen species.

cells. ${ }^{31,32}$ In the normal cultivation (control group), HUVECs exhibited cobblestone phenotype, and the intercellular junction between the cells was clear and side-by-side with laser confocal microscopy observation (Figure S1). After $1 \mathrm{hr}$ of incubation with the NPs, the VE-cadherin on the membrane became blur (Figure 5A), and at the same time, the expression of VE-cadherin in the whole cell was decreased in reference to that in the control (Figure 5B), both of which indicated that the adherens junction was not so tightly together between cells. Images from the confocal observation for cells incubated with the NPs with various sizes and coatings were given in Figure S2. We further measured the gapwidth of intercellular junctions, and the measurement approach was illustrated in Figure S3 according to the reference. ${ }^{33}$ Strikingly, after incubated with NPs at their non- cytotoxic concentrations for $1 \mathrm{hr}$, intercellular gaps were detected in all the groups except for cells incubation with $\mathrm{Au}$ NPs (Figure 5C), though no statistical difference was shown among the size, coating, and component. The permeability of endothelial monolayer pre-treated with different NPs was also evaluated using the assay of $40-\mathrm{kD}$ FITCdextran movement across the monolayer, ${ }^{14}$ results were consistent with the statistical result of gap formation (Figure S4).

\section{Rescue on adherens junction of HUVECs}

We next investigated whether the NPs-induced gap formation in HUVECs could be rescued by antioxidantNAC. It was seen that the pre-incubation with NAC has no effect on the control group. However, in the NPs treated group, pre-incubation with NAC could decrease the level of NPs 


\section{A}

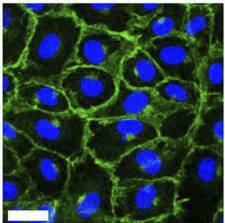

Control

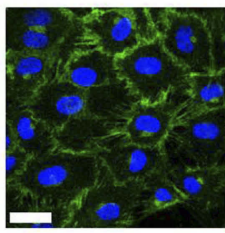

$\mathrm{SiO}_{2} 100$

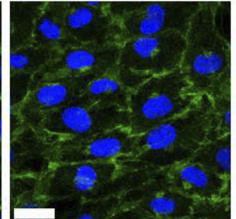

Au-50

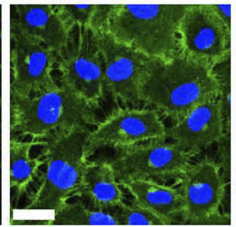

$\mathrm{TiO}_{2} 100$

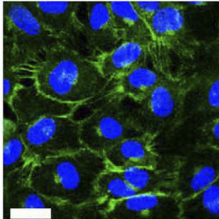

Pt-70

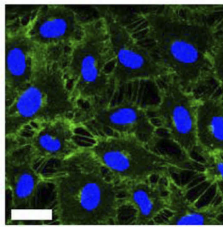

DMSA- $\mathrm{Fe}_{2} \mathrm{O}_{3}$

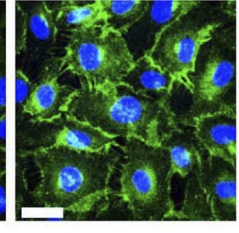

MWCNTs

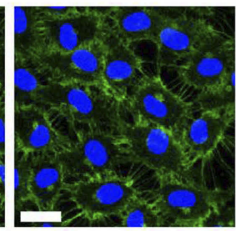

Dex- $-\mathrm{Fe}_{2} \mathrm{O}_{3}$

VE-Cadherin

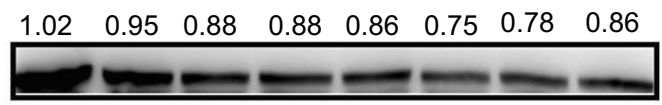

$\beta$-actin

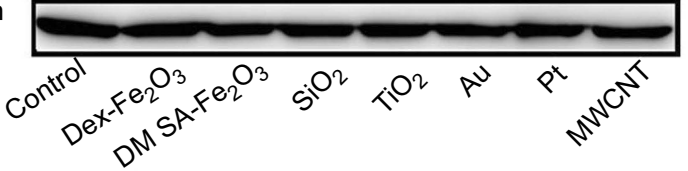

c

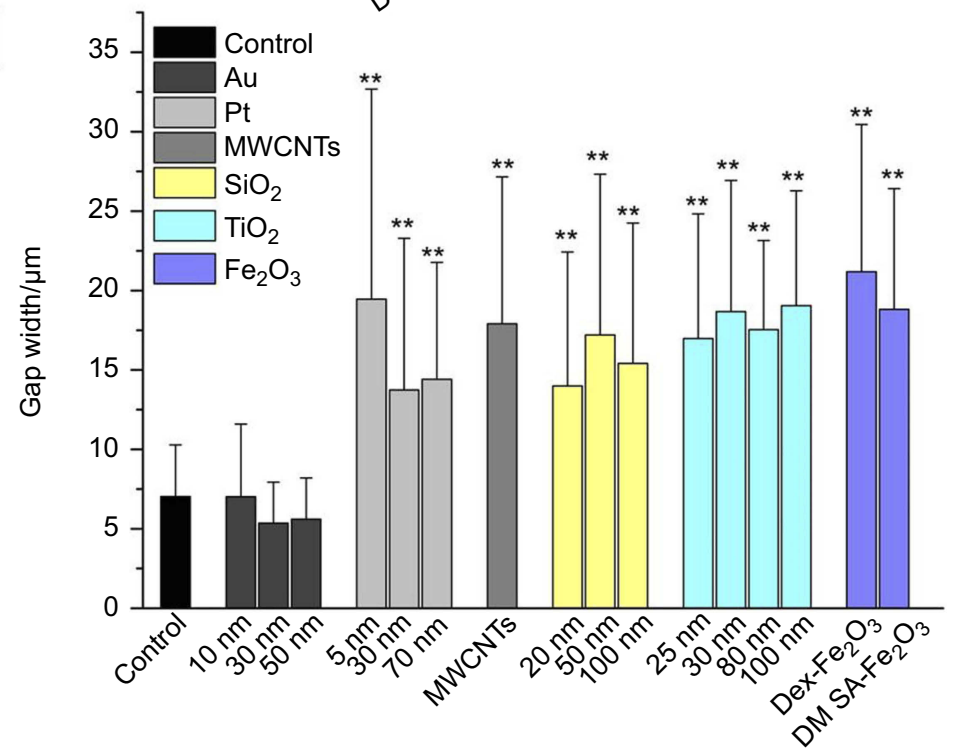

Figure 5 (A) Effects of NPs on the adherens junction of HUVECs were observed from confocal microscope. Scale bar is $20 \mu \mathrm{m}$. (B) Western-blot result of VE-cadherin

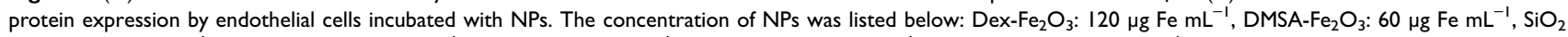
(100 nm): $25 \mu \mathrm{g} \mathrm{mL} \mathrm{L}^{-1}, \mathrm{TiO}_{2}(25 \mathrm{~nm}): 25 \mu \mathrm{g} \mathrm{mL} \mathrm{L}^{-1}$, Pt $(70 \mathrm{~nm}):$ I $\mu \mathrm{g} \mathrm{mL} \mathrm{L}^{-1}$, Au $(50 \mathrm{~nm}): 200 \mu \mathrm{gL}^{-1}$, and MWCNTs: $7.5 \mu \mathrm{mL} \mathrm{m}^{-1}$. (C) Gap widths between cells treated by NPs which calculated from 10 groups. **: $P<0.01$ compared with the control group.

Abbreviation: HUVECs, human umbilical vein endothelial cells.

mediated ROS production effectively, and the gaps between the cells were reduced as well (Figure 6), which strongly suggested that the NP-induced excess ROS in the HUVECs led to the reduction of cell-cell adherens junction and, lastly, induced gap formation and resulted in the permeability of the endothelial layer. At the same time, these results suggested that the NPs induced gap formation could be rescued by the treatment of antioxidant.

\section{Discussion}

Due to their specific and unique nanoscale physicochemical properties, NPs have emerged as powerful tools for a wide scope of applications such as in nanomedicine. For example, plasmonic NPs, including $\mathrm{Au}$ and $\mathrm{Pt}$, were employed in sensing, drug delivery, photoacoustic imaging, photothermal therapy, and photodynamic therapy. ${ }^{34}$ 


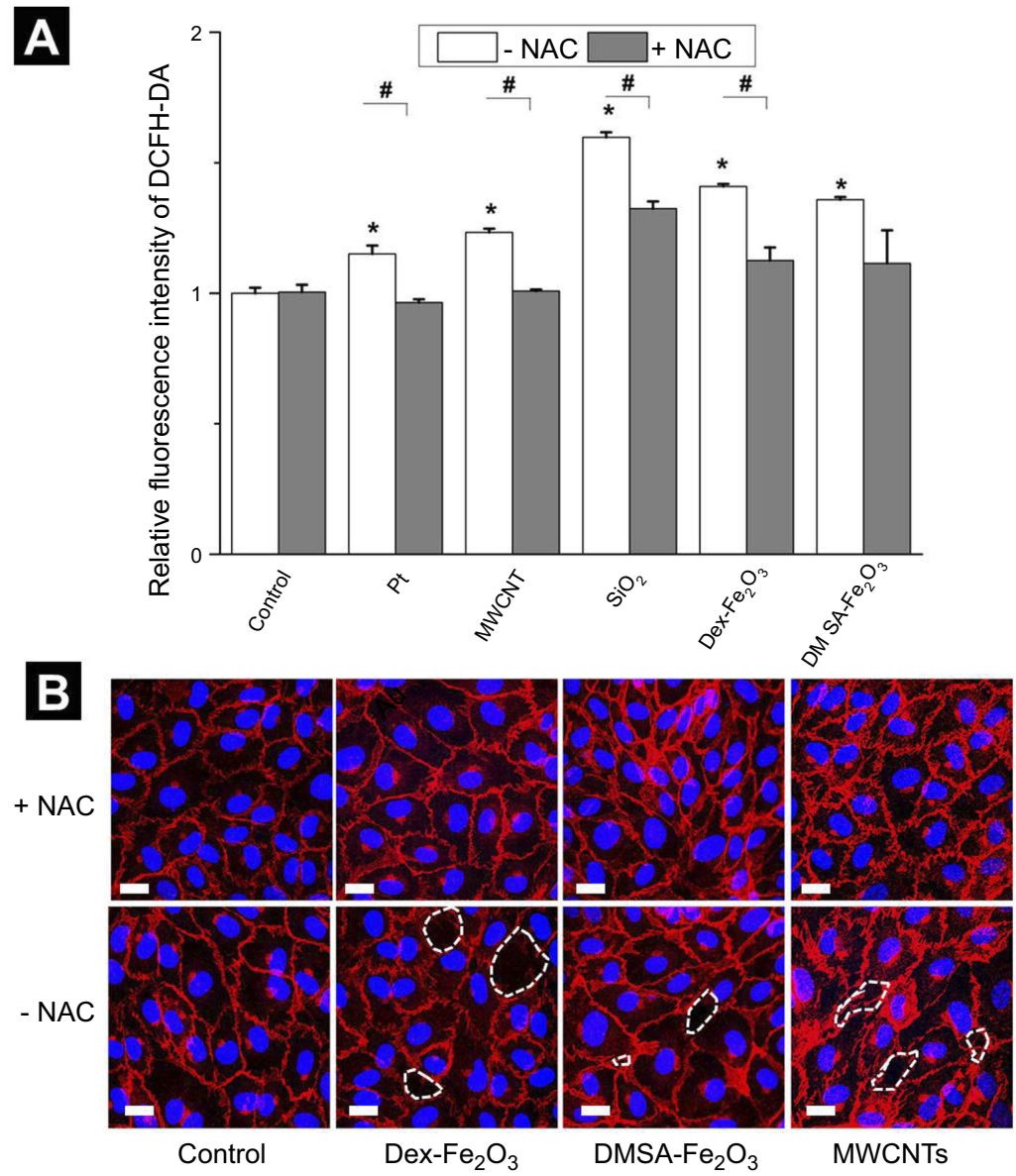

Figure $6(\mathbf{A})$ The intracellular ROS level caused by NPs in the absent and present of NAC. The * represents a significant difference comparing with the control group (*: P<0.05), and the \# indicates a significant difference between the NAC group and the without NAC pre-treatment group (\#: $P<0.05)$. (B) Confocal images in the absent and present of 3 mM NAC. The scale bar is $20 \mu \mathrm{m}$ for all. The concentration of NPs was following: $\mathrm{Pt}(70 \mathrm{~nm}): 1 \mu \mathrm{g} \mathrm{mL}{ }^{-1}, \mathrm{MWCNTs} 7.5 \mu \mathrm{mL}^{-1}, \mathrm{SiO}_{2}(100 \mathrm{~nm}): 25 \mu \mathrm{gL} \mathrm{L}^{-1}, \mathrm{Dex}-\mathrm{Fe}_{2} \mathrm{O}_{3}: 30 \mu g \mathrm{Fe} \mathrm{mL}^{-1}$, and DMSA-Fe $\mathrm{O}_{3}: 30 \mu \mathrm{g} \mathrm{Fe} \mathrm{mL}^{-1}$.

Abbreviation: NAC, $\mathrm{N}$-acetylcysteine.

MWCNT, with the characters of lightweight, extreme strength and tensile forces, electronic conductivity, and strong capillary forces, have a broad application in supercapacitors, automotive industry, aerospace industry, pharmaceutics, and medical devices. ${ }^{11,35}$ With large surface area, high structural stability, easy surface functionalization, low cost of production, and excellent biocompatibility, metal oxide NPs (such as $\mathrm{SiO}_{2}, \mathrm{TiO}_{2}$, and $\mathrm{Fe}_{2} \mathrm{O}_{3}$ ) were researched and used in drug, protein or gene delivery, cosmetics doping, and imaging enhancements. ${ }^{18,34,36}$ Therefore, it is necessary to systematically and comparatively evaluate the effects of above typical NPs in biological systems.

As mentioned in the introduction, major previous studies were performed upon vascular endothelial cells at cytotoxic concentrations. ${ }^{9,12,15,37}$ In our opinions, effects of NPs at acutely non-cytotoxic concentration on endothelial cells are particularly worthy to note, because there may be some unseen biological effects. Therefore, non-acute cytotoxic concentrations were set for each kind of NPs employed in this study to assure the relative viability of cells was higher than $80 \%$ (comparing with the control group), which is considered as non-toxic or slight cytotoxic and clinically acceptable according to the guidance of ISO for biological evaluation of medical devices. $^{38}$

Our results suggested that even at a concentration of not inducing cell death significantly, the NPs were able to affect the expression of VE-cadherin between vascular endothelial cells by inducing oxidative stress, though this effect is reported in previous literatures with cytotoxic exposure. The downregulation of VE-cadherin induced by the NPs led the gap formation between the HUVECs, might lead a dysfunction of ECs. ${ }^{19}$ Nevertheless, it could 
be noticed that the decrease of VE-cadherin could be rescued by employing the antioxidant, which is in consistence with the results reported previously. ${ }^{39,40}$ Furthermore, the decrease of VE-cadherin and the gap formation between the vascular endothelial cells exerted by the NPs were associated with the morphology, size, and coatings of NP, which was ubiquitous, but there was a matter of degree.

HUVECs that cover the lumen of blood vessels have been considered as a general model for access the toxicity of NPs. ${ }^{41}$ There are two prevailing paradigms on how NPs traverse across endothelial barriers. ${ }^{42}$ One is a transcellular process with energetically costly and slow, the other is a paracellular transport process with crossing cell barriers by diffusion between cells through the cell-cell junctions. In drug-based therapies, the alteration of permeability barrier integrity plays a major role when drugs either small biomolecules or NPs employ the paracellular transport process, the leakiness may provide an easier journey for the NPs. Thus, this tuneable influence with size and/or coating related to adherens junction of endothelial cells might contribute to the regulation on enhanced permeability and retention effect in drug delivery system.

In this work, we proposed the generality and specificity of various NPs to the endothelial cells, which provided a new insight into the safety evaluation of NPs in applications, especially would be benefit to the establishment of standard assays in the future to predict or evaluate the NP-mediated potential risks to vascular endothelial cells as well as monolayers by measuring oxidative stress (ROS or/and CAT detection) simply, and those effects may not be detected by using conventional cytotoxicity assays. Nevertheless, gene-related studies need to be further conducted in the future. So far there are only a few of studies from gene level for NPs upon endothelial cells have been reported. ${ }^{43-46}$ For example, Ag NPs induce excess ROS production of HUVECs by activation of nicotinamide adenine dinucleotide phosphate (NADPH) oxidase activity through upregulation of NADPH oxidase 4 (NOX4) gene, ${ }^{43}$ increase the permeability of rat brain microvascular endothelial cells by inhibiting the antioxidant defence of the astrocytes that inhibits the Trx system, and decreasing Nr4a1 and Dusp1 gene. ${ }^{45}$ Hydroxyapatite NPs down-regulated VE-cadherin and CD31 gene of ECs. ${ }^{44}$

\section{Conclusion}

In summary, we employed a small library of NPs to show that the exposure of NPs to HUVECs at the concentration of low cytotoxicity induced the upregulation of intracellular ROS and increased the antioxidant (CAT) activity at the same time, which led to the downregulation of VE-cadherin. These effects resulted in the formation of gaps between the cells and induced endothelial leakiness. Thus, even if the NPs applied at non-cytotoxic concentration, NP-mediated ROS should be prevented to reduce the negative effects on the integrity of endothelial barriers and risk of vascular diseases.

\section{Acknowledgments}

This work was supported by the National Key R\&D Program of China (2017YFA0205504), National Natural Science Foundation of China (81801771), and CAMS Innovation Fund for Medical Sciences (CIFMS 2016I2M-3-004 and 2018-I2M-3-006).

\section{Author contributions}

All authors contributed to data analysis, drafting or revising the article, gave final approval of the version to be published, and agree to be accountable for all aspects of the work.

\section{Disclosure}

The authors report no conflicts of interest in this work.

\section{References}

1. Barreto JA, O'Malley W, Kubeil M, Graham B, Stephan H, Spiccia L Nanomaterials: applications in cancer imaging and therapy. $A d v$ Mater. 2011;23(12):H18-H40. doi:10.1002/adma.201100140

2. Zhu M-T, Wang B, Wang Y, et al. Endothelial dysfunction and inflammation induced by iron oxide nanoparticle exposure: risk factors for early atherosclerosis. Toxicol Lett. 2011;203(2):162-171. doi:10.1016/j.toxlet.2011.03.021

3. Albini A, Mussi V, Parodi A, et al. Interactions of single-wall carbon nanotubes with endothelial cells. Nanomedicine. 2010;6(2):277-288. doi:10.1016/j.nano.2009.08.001

4. Alom-Ruiz SP, Anilkumar N, Shah AM Reactive oxygen species and endothelial activation. Antioxid Redox Signal. 2008;10 (6):1089-1100. doi:10.1089/ars.2007.2007

5. Freese C, Schreiner D, Anspach L, et al. In vitro investigation of silica nanoparticle uptake into human endothelial cells under physiological cyclic stretch. Part Fibre Toxicol. 2014;11:68. doi:10.1186/s12989-014-0068-y

6. Khanna P, Ong C, Bay B, Baeg G Nanotoxicity: an interplay of oxidative stress, inflammation and cell death. Nanomaterials. 2015;5(3):1163. doi:10.3390/nano5031163

7. Davda J, Labhasetwar V Characterization of nanoparticle uptake by endothelial cells. Int J Pharm. 2002;233:51-59.

8. Choy JC, Granville DJ, Hunt DW, McManus BM Endothelial cell apoptosis: biochemical characteristics and potential implications for atherosclerosis. J Mol Cell Cardiol. 2001;33(9):1673-1690. doi:10.1006/jmcc.2001.1419

9. Setyawati MI, Tay CY, Bay BH, Leong DT Gold nanoparticles induced endothelial leakiness depends on particle size and endothelial cell origin. ACS Nano. 2017;11(5):5020-5030. doi:10.1021/acsnano.7b01744

10. Zheng W, Jiang B, Hao Y, Zhao Y, Zhang W, Jiang X Screening reactive oxygen species scavenging properties of platinum nanoparticles on a microfluidic chip. Biofabrication. 2014;6(4):045004. doi:10.1088/1758-5082/6/4/045004 
11. Pacurari M, Qian Y, Fu W, et al. Cell permeability, migration, and reactive oxygen species induced by multiwalled carbon nanotubes in human microvascular endothelial cells. J Toxicol Environ Health A. 2012;75(2):112-128. doi:10.1080/15287394.2011.615110

12. Liu X, Sui B, Sun J Blood-brain barrier dysfunction induced by silica NPs in vitro and in vivo: involvement of oxidative stress and Rho-kinase/JNK signaling pathways. Biomaterials. 2017;121:64-82. doi:10.1016/j.biomaterials.2017.01.006

13. Tay CY, Setyawati MI, Leong DT Nanoparticle density: a critical biophysical regulator of endothelial permeability. ACS Nano. 2017;11 (3):2764-2772. doi:10.1021/acsnano.6b07806

14. Setyawati MI, Tay CY, Chia SL, et al. Titanium dioxide nanomaterials cause endothelial cell leakiness by disrupting the homophilic interaction of VE-cadherin. Nat Commun. 2013;4:1673. doi:10.1038/ncomms2655

15. Hou Y, Lai M, Chen X, et al. Effects of mesoporous SiO2, Fe3 O4, and $\mathrm{TiO} 2$ nanoparticles on the biological functions of endothelial cells in vitro. J Biomed Mater Res A. 2014;102(6):1726-1736. doi:10.1002/jbm.a.34839

16. Qiu Y, Tong S, Zhang L, et al. Magnetic forces enable controlled drug delivery by disrupting endothelial cell-cell junctions. Nat Commun. 2017;8:15594. doi:10.1038/ncomms15594

17. Apopa PL, Qian Y, Shao R, et al. Iron oxide nanoparticles induce human microvascular endothelial cell permeability through reactive oxygen species production and microtubule remodeling. Part Fibre Toxicol. 2009;6:1. doi:10.1186/1743-8977-6-1

18. Sun J, Wang S, Zhao D, Hun FH, Weng L, Liu H Cytotoxicity, permeability, and inflammation of metal oxide nanoparticles in human cardiac microvascular endothelial cells: cytotoxicity, permeability, and inflammation of metal oxide nanoparticles. Cell Biol Toxicol. 2011;27(5):333-342. doi:10.1007/s10565-011-9191-9

19. Wu X, Tan Y, Mao H, Zhang M Toxic effects of iron oxide nanoparticles on human umbilical vein endothelial cells. Int J Nanomedicine. 2010;5:385-399.

20. Ma X, Hartmann R, Jimenez de Aberasturi D, et al. Colloidal gold nanoparticles induce changes in cellular and subcellular morphology. ACS Nano. 2017;11(8):7807-7820. doi:10.1021/acsnano.7b01760

21. Guo H, Zhang J, Boudreau M, et al. Intravenous administration of silver nanoparticles causes organ toxicity through intracellular ROS-related loss of inter-endothelial junction. Part Fibre Toxicol. 2016;13:21. doi:10.1186/s12989-016-0133-9

22. Meng J, Cheng X, Liu J, et al. Effects of long and short carboxylated or aminated multiwalled carbon nanotubes on blood coagulation. PLoS One. 2012;7(7):e38995. doi:10.1371/journal.pone.0038995

23. Jordi P, Neus G, Victor P. Size-controlled synthesis of sub-10nanometer citrate-stabilized gold nanoparticles and related optical properties. Chem Mater. 2016;28:1066-1075. doi:10.1021/acs. chemmater.5b04406

24. Bastus NG, Comenge J, Puntes V Kinetically controlled seeded growth synthesis of citrate-stabilized gold nanoparticles of up to $200 \mathrm{~nm}$ : size focusing versus Ostwald ripening. Langmuir. 2011;27 (17):11098-11105. doi:10.1021/la201938u

25. Uboldi C, Bonacchi D, Lorenzi G, et al. Gold nanoparticles induce cytotoxicity in the alveolar type-II cell lines A549 and NCIH441. Part Fibre Toxicol. 2009;6:18. doi:10.1186/1743-8977-6-18

26. Freese C, Uboldi C, Gibson MI, et al. Uptake and cytotoxicity of citrate-coated gold nanospheres: comparative studies on human endothelial and epithelial cells. Part Fibre Toxicol. 2012;9:23. doi:10.1186/1743-8977-9-23

27. Duan J, Yu Y, Li Y, et al. Toxic effect of silica nanoparticles on endothelial cells through DNA damage response via Chk1-dependent G2/M checkpoint. PLoS One. 2013;8(4):e62087. doi:10.1371/journal. pone.0062087

28. Davalli P, Mitic T, Caporali A, Lauriola A, D'Arca D ROS, cell senescence, and novel molecular mechanisms in aging and age-related diseases. Oxid Med Cell Longev. 2016;2016:3565127. doi:10.1155/2016/3565127
29. Guo C, Xia Y, Niu P, et al. Silica nanoparticles induce oxidative stress, inflammation, and endothelial dysfunction in vitro via activation of the MAPK/Nrf2 pathway and nuclear factor-kappaB signaling. Int J Nanomedicine. 2015;10:1463-1477. doi:10.2147/IJN.S76114

30. Alarifi S, Ali D, Alakhtani S, Al Suhaibani ES, Al-Qahtani AA Reactive oxygen species-mediated DNA damage and apoptosis in human skin epidermal cells after exposure to nickel nanoparticles. Biol Trace Elem Res. 2014;157(1):84-93. doi:10.1007/s12011-013-9871-9

31. Dejana E, Giampietro C Vascular endothelial-cadherin and vascular stability. Curr Opin Hematol. 2012;19(3):218-223. doi:10.1097/ MOH.0b013e3283523e1c

32. Harris ES, Nelson WJ VE-cadherin: at the front, center, and sides of endothelial cell organization and function. Curr Opin Cell Biol. 2010;22(5):651-658. doi:10.1016/j.ceb.2010.07.006

33. Huynh J, Nishimura N, Rana K, et al. Age-related intimal stiffening enhances endothelial permeability and leukocyte transmigration. Sci Transl Med. 2011;3(112):112ra122. doi:10.1126/scitranslmed.3002761

34. Feliu N, Docter D, Heine M, et al. In vivo degeneration and the fate of inorganic nanoparticles. Chem Soc Rev. 2016;45(9):2440-2457. doi: $10.1039 / \mathrm{c} 5 \mathrm{cs} 00699 \mathrm{f}$

35. Snyder-Talkington BN, Schwegler-Berry D, Castranova V, Qian Y, Guo NL Multi-walled carbon nanotubes induce human microvascular endothelial cellular effects in an alveolar-capillary co-culture with small airway epithelial cells. Part Fibre Toxicol. 2013;10(35). doi:10.1186/1743-8977-10-56

36. Chen X, Mao SS Titanium dioxide nanomaterials: synthesis, properties, modifications, and applications. Chem Rev. 2007;107:2891-2959. doi:10.1021/cr0500535

37. Astanina K, Simon Y, Cavelius C, Petry S, Kraegeloh A, Kiemer AK Superparamagnetic iron oxide nanoparticles impair endothelial integrity and inhibit nitric oxide production. Acta Biomater. 2014;10 (11):4896-4911. doi:10.1016/j.actbio.2014.07.027

38. International Organization for Standardization (ISO). ISO Specifcation 10993-10995: Biological Evaluation of Medical Devices - Part 5: Tests for In Vitro Cytotoxicity. 3rd ed. Geneva, Switzerland: ISO; 2009.

39. Jeong CH, Seok JS, Petriello MC, Han SG Arsenic downregulates tight junction claudin proteins through p38 and NF-kappaB in intestinal epithelial cell line, HT-29. Toxicology. 2017;379:31-39. doi:10.1016/j.tox.2017.01.011

40. Beconcini D, Fabiano A, Zambito Y, et al. Chitosan-based nanoparticles containing cherry extract from Prunus avium L. to improve the resistance of endothelial cells to oxidative stress. Nutrients. 2018;10:1598. doi:10.3390/nu10111598

41. Cao Y, Gong Y, Liu L, et al. The use of human umbilical vein endothelial cells (HUVECs) as an in vitro model to assess the toxicity of nanoparticles to endothelium: a review. J Appl Toxicol. 2017;37 (12):1359-1369. doi:10.1002/jat.3470

42. Setyawati MI, Tay CY, Leong DT The gap between endothelial cells: key to the quick escape of nanomaterials? Nanomedicine. 2014;9 (11):1591-1594. doi:10.2217/nnm.14.104

43. Sun X, Yang Y, Shi J, Wang C, Yu Z, Zhang H NOX4- and Nrf2-mediated oxidative stress induced by silver nanoparticles in vascular endothelial cells. J Appl Toxicol. 2017;37(12):1428-1437. doi:10.1002/jat.3511

44. Santos C, Turiel S, Gomes PS, et al. Vascular biosafety of commercial hydroxyapatite particles: discrepancy between blood compatibility assays and endothelial cell behavior. J Nanobiotechnology. 2018;16:27. doi:10.1186/s12951-018-0357-y

45. Xu L, Dan M, Shao A, et al. Silver nanoparticles induce tight junction disruption and astrocyte neurotoxicity in a rat blood-brain barrier primary triple coculture model. Int $J$ Nanomedicine. 2015;10:6105-6119. doi:10.2147/IJN.S85265

46. Hosoo H, Marushima A, Nagasaki Y, et al. Neurovascular unit protection from cerebral ischemia-reperfusion injury by radicalcontaining nanoparticles in mice. Stroke. 2017;48(8):2238-2247. doi:10.1161/STROKEAHA.116.016356 


\section{Supplementary materials}

\section{Experimental Section}

Synthesis of Gold Nanoparticles

1. Small size-10 nm: $150 \mathrm{~mL}$ of reduced solution of sodium citrate (SC, $2.2 \mathrm{mM}$, Sinopharm Chemical Reagent Co., Ltd) containing $0.1 \mathrm{~mL}$ tannic acid (TA, $2.5 \mathrm{mM}$, Aladdin, Shanghai) and $1 \mathrm{~mL}$ potassium carbonate $\left(\mathrm{K}_{2} \mathrm{CO}_{3}, 150 \mathrm{mM}\right.$, Aladdin, Shanghai) was heated (temperature set at $70^{\circ} \mathrm{C}$ ) in a $250 \mathrm{~mL}$ threenecked bottom flask under severe stirring. One milliliter tetra chloroauric acid $\left(\mathrm{HAuCl}_{4}, 25 \mathrm{mM}\right.$, Sinopharm Chemical Reagent Co., Ltd) was slowly injected when the temperature was reached. The color of the solution quickly turns into black gray (less than $10 \mathrm{~s}$ ) and then turns into orange red subsequently. The solution was kept at $70^{\circ} \mathrm{C}$ for 10 mins to guarantee complete reaction of the gold nanoparticle. ${ }^{1}$
2. Large size-30 nm: $150 \mathrm{~mL}$ of the reduced solution of sodium citrate (SC, $2.2 \mathrm{mM}$ ) was heated (temperature set on $100^{\circ} \mathrm{C}$ ) in a heating mantle in a $250 \mathrm{~mL}$ threenecked bottom flask under severe stirring. When the temperature reached $96^{\circ} \mathrm{C}, 1 \mathrm{~mL}$ of tetra chloroauric acid $\left(\mathrm{HAuCl}_{4}, 25 \mathrm{mM}\right)$ was injected slowly. The color of the solution quickly turns into black gray (less than $10 \mathrm{~s}$ ) and then turns into orange red subsequently. The solution was kept at $100^{\circ} \mathrm{C}$ for 20 mins to ensure complete reaction of the gold precursor. After 20 mins, the reaction was cooled down until the temperature of the solution reached $90^{\circ} \mathrm{C}$. Then, $1 \mathrm{~mL}$ of sodium citrate $(60 \mathrm{mM})$ and $1 \mathrm{~mL}$ of $\mathrm{HAuCl}_{4}$ solution (25 mM) were sequentially injected (time delay about 2 mins). 30 mins later, repeated once, then turn off the heat and stir for another 20 mins. $^{2}$

3. Large size-50 nm: Gold nanoparticles were prepared just like $30 \mathrm{~nm}$. Repeat subsequent steps four times, then turn off the heat and stir for another 20 mins.
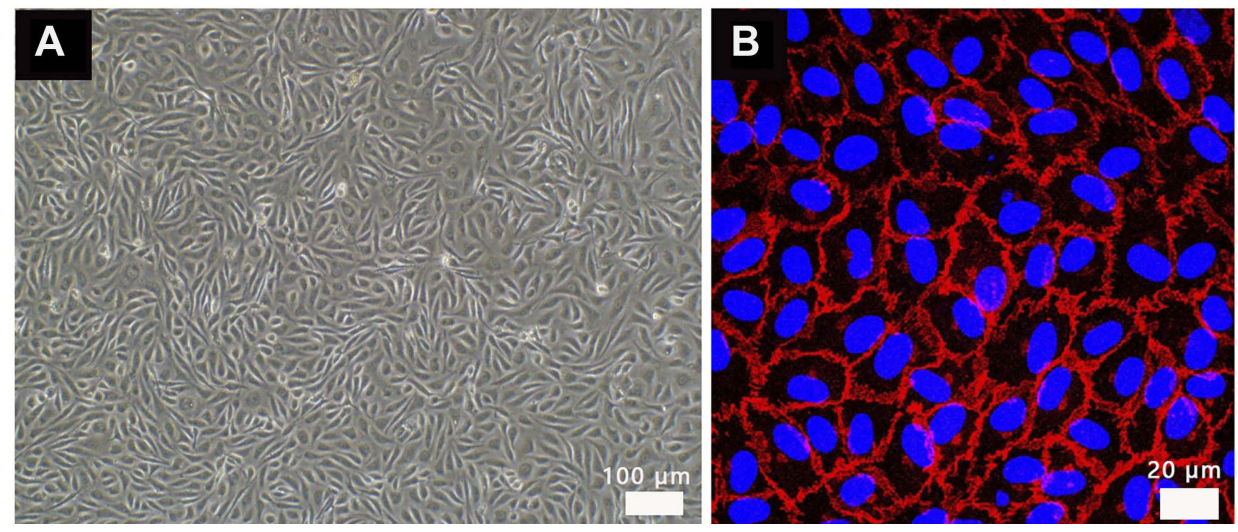

Figure SI Images of HUVEC in endothelial cell medium from (A) optical microscope, HUVECs were paved stone-like growth and (B) confocal labeled with VE-cadherin antibody (red) and DAPI (blue). Normal umbilical vein endothelial cells connected closely.

Abbreviation: HUVECs, human umbilical vein endothelial cells. 


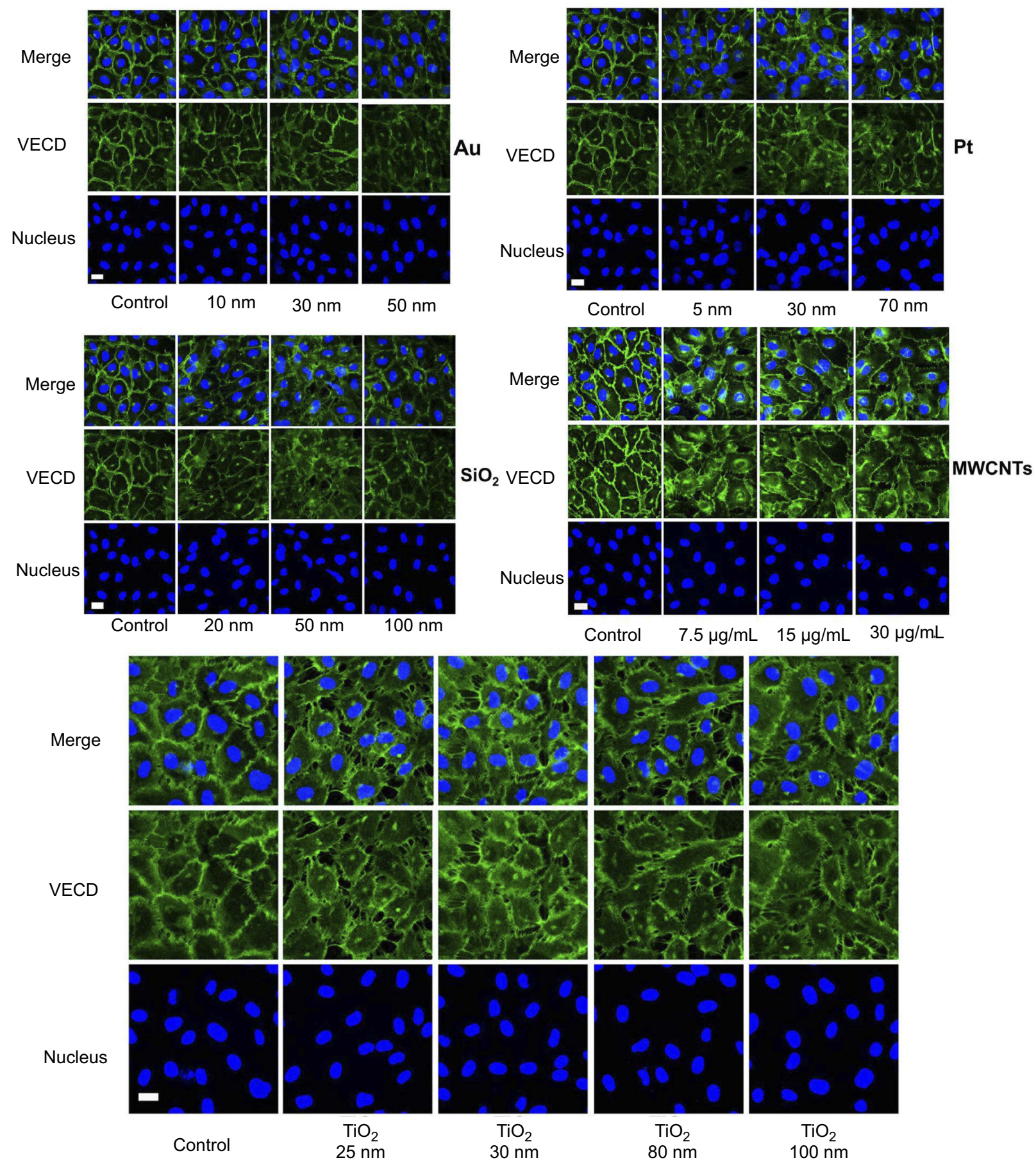

Figure S2 Effects on the adherens junction of HUVEC with various nanoparticles of different size, coating, and concentration. Images are taken from confocal labeled with VE-

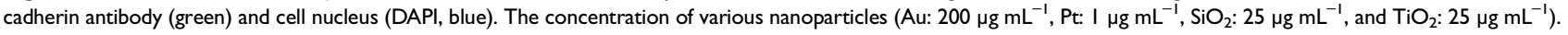
Abbreviations: VECD, VE-cadherin; DAPI, 4',6-diamidino-2-phenylindole. 
A

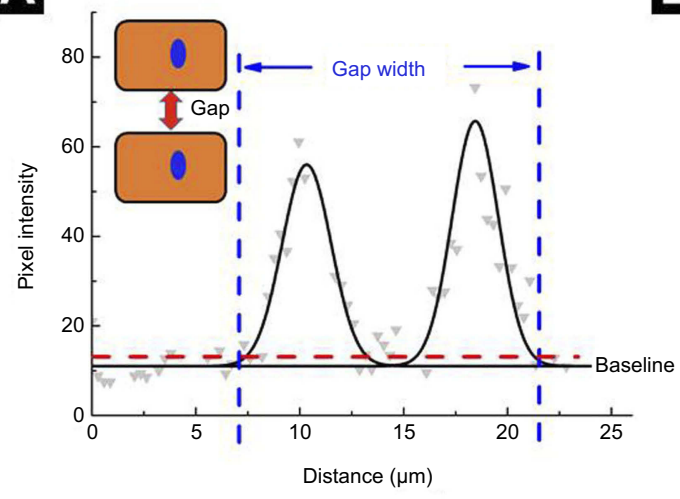

B

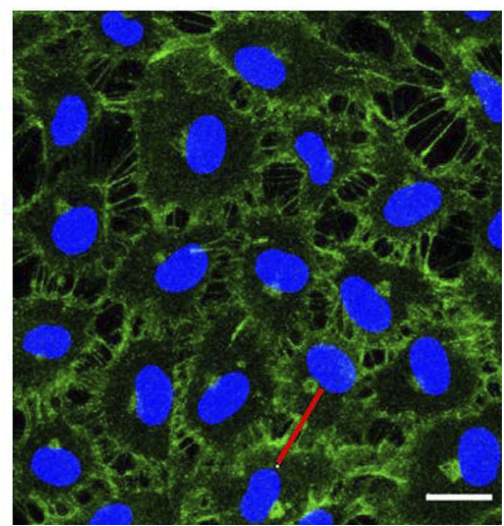

Figure S3 Measurement of gap-width. (A) Gray dots represent the pixel intensity profile of the red line drawn in (B), whereas the black line represents a two-Gaussian fit. The junction width was considered as the width of the fitted curve at $20 \%$ above baseline intensity, as indicated by the dashed red line. (B) Images from a confocal microscope. Scale bar is $20 \mu \mathrm{m}$.
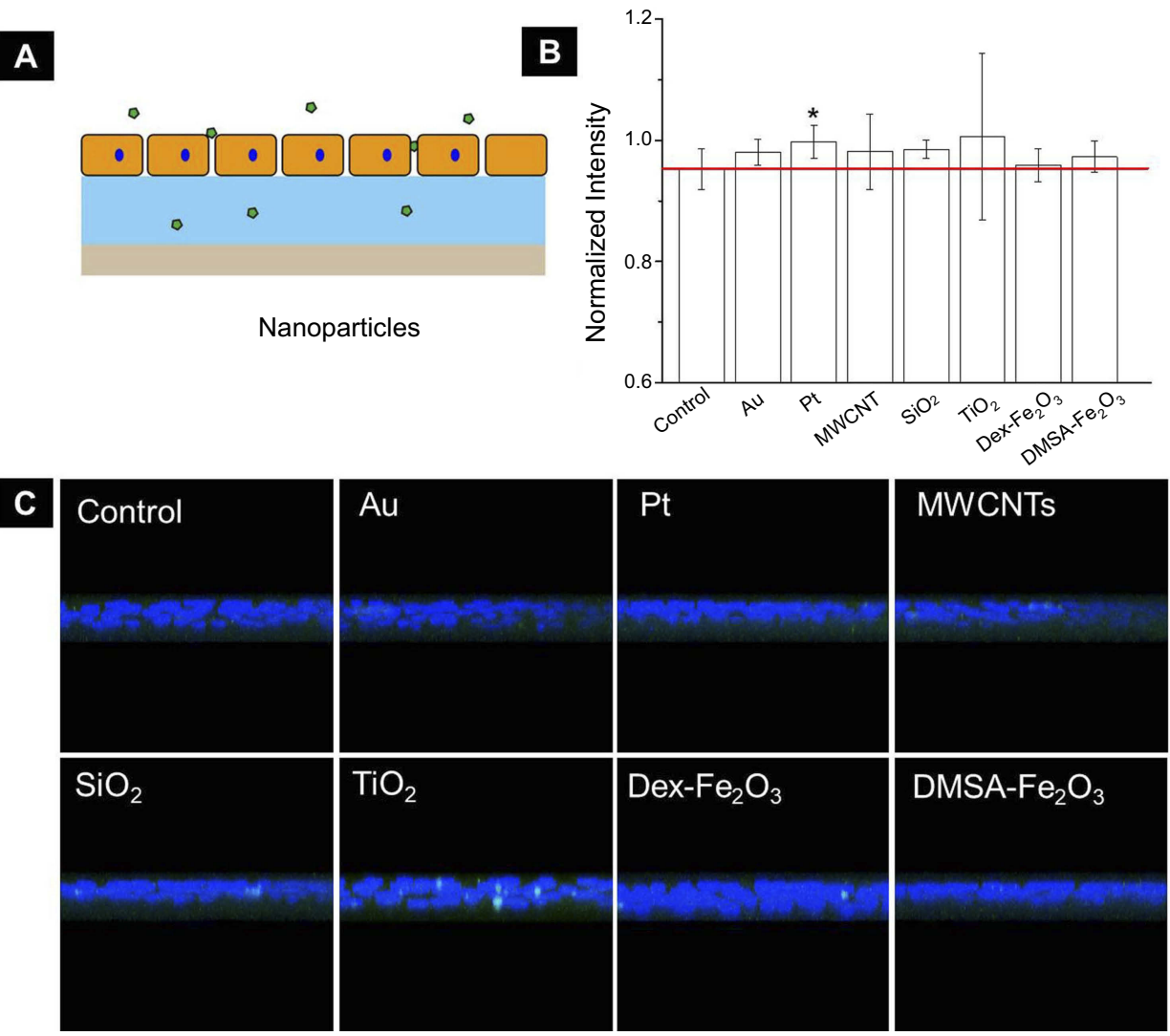

Figure S4 (A) The schematic diagram shows FITC-dextran permeating the collagen layer through a monolayer of endothelial cells. (B) Monolayer permeability was measured in samples that were untreated or treated with NPs for I hr. Data were shown as average mean \pm SE from five groups of confocal images. (C) The representative $\mathrm{YZ}$ confocal cross-section images of the dextran captured in the $2 \mu \mathrm{g} \mathrm{cm}$ collagen, fluorescent images showing nuclei (blue), and FITC-dextran (green) of confluent HUVECs on collagen. The concentration of NPs was following: Au $(50 \mathrm{~nm}): 200 \mu \mathrm{g} \mathrm{mL} \mathrm{L}^{-1}, \mathrm{Pt}(70 \mathrm{~nm}): 1 \mu \mathrm{g} \mathrm{mL} \mathrm{L}^{-1}, \mathrm{MWCNTs} 7.5 \mu \mathrm{g} \mathrm{mL} \mathrm{L}^{-1}, \mathrm{SiO}_{2}(100 \mathrm{~nm}): 25 \mu \mathrm{mL} \mathrm{L}^{-1}, \mathrm{TiO}_{2}$ $(80 \mathrm{~nm}): 25 \mu \mathrm{g} \mathrm{mL}{ }^{-1}$, Dex- $\mathrm{Fe}_{2} \mathrm{O}_{3}: 30 \mu \mathrm{g} \mathrm{Fe} \mathrm{mL}{ }^{-1}$, and DMSA-Fe $\mathrm{O}_{3}: 30 \mu \mathrm{g} \mathrm{Fe} \mathrm{mL} \mathrm{m}^{-1}$.

Abbreviation: FITC, fluorescein isothiocyante. 


\section{References}

1. Jordi P, Neus GB, Victor P. Size-controlled synthesis of sub-10-nanometer citrate-stabilized gold nanoparticles and related optical properties. Chem Mate. 2016; 28(4):1066-1075. doi:org/10.1021/acs.chemmater.5b04406
2. Bastus NG, Comenge J, Puntes V Kinetically controlled seeded growth synthesis of citrate-stabilized gold nanoparticles of up to $200 \mathrm{~nm}$ : size focusing versus Ostwald ripening. Langmuir. 2011;27 (17):11098-11105. doi:10.1021/la201938u

\section{Publish your work in this journal}

The International Journal of Nanomedicine is an international, peerreviewed journal focusing on the application of nanotechnology in diagnostics, therapeutics, and drug delivery systems throughout the biomedical field. This journal is indexed on PubMed Central, MedLine, CAS, SciSearch ${ }^{\mathbb{R}}$, Current Contents ${ }^{\mathbb{B}} /$ Clinical Medicine,
Journal Citation Reports/Science Edition, EMBase, Scopus and the Elsevier Bibliographic databases. The manuscript management system is completely online and includes a very quick and fair peer-review system, which is all easy to use. Visit http://www.dovepress.com/ testimonials.php to read real quotes from published authors.

Submit your manuscript here: https:/www.dovepress.com/international-journal-of-nanomedicine-journal 